Annals of Warsaw University of Life Sciences - SGGW

Land Reclamation No 46 (3), 2014: 205-220

(Ann. Warsaw Univ. of Life Sci. - SGGW, Land Reclam. 46 (3), 2014)

\title{
Predicted small catchment responses to heavy rainfalls with SEGMO and two sets of model parameters
}

\author{
ADAM KRAJEWSKI ${ }^{1}$, HYOSANG LEE ${ }^{2}$, LESZEK HEJDUK ${ }^{1}$, \\ KAZIMIERZ BANASIK ${ }^{1}$ \\ ${ }^{1}$ Department of Water Engineering, Warsaw University of Life Sciences - SGGW \\ ${ }^{2}$ School of Civil Engineering, Chungbuk National University
}

\begin{abstract}
Predicted small catchment responses to heavy rainfalls with SEGMO and two sets of model parameters. The study tests the ability of hydrological part of SEGMO (SedimentGraph Model), i.e. lumped parametric rainfall-runoff procedure of SEGMO to simulate design storm runoff in a Korean catchment. The aim of the investigation is to predict responses of small catchment of the Jeungpyeong river, located in central part of South Korea, with the area of $133.6 \mathrm{~km}^{2}$, to 100 -year rainfall events, applying SEGMO and using two parallel approaches for model parameter estimation. The first approach is based on catchment characteristics and USDA-SCS procedures, which is suitable for ungauged basins, and the other one is based on rainfall-runoff measurements. The way of estimation of model parameters has been demonstrated. Finally, the model outputs are compared. The difference in largest peak discharges obtained from SEGMO with the two sets of model parameters, i.e. when estimated on the base of catchment characteristics and USDA-SCS procedures, and on the base of rainfall-runoff measurements were relatively small, approaching $37 \%$. This investigation can be seen as checking the uncertainties in model parameter estimation and their influence on flood flows.
\end{abstract}

Key words: rainfall-runoff, SEGMO model, SCS Curve Number, Nash IUH, Jeungpyeong river

\section{INTRODUCTION}

Floods cause social, environmental and economic damages. They devastate households, infrastructure, crops, monu- ments and threaten people's live. Consequences of this extreme events are very expensive. Costs of floods, which occurred in Poland in 2010 were estimated on 3 billion euro (PAP 2010). Due to observed climate changes (higher temperature, increased precipitation and runoff) flood hazard will be impacting more people globally (Andersen and Shepherd 2013). That is why policymakers, planners and designers need information about magnitude of expected flood in order to guarantee safety (Eash 1993). On the other hand delivered information should be reliable (Castellarin et al. 2012, Sikorska et al. 2013), what gives possibility to properly balance both spending and risk.

In gauged catchments design discharge can be estimated applying the flood frequency analysis (Banasik et al. 2012, Pekárová et al. 2013, Strupczewski et al. 2014). In case of majority of small catchments, there are no long-term monitoring data (Sikorska and Banasik 2010, Karabová et. al. 2012), so it becomes impossible to apply direct (statistical) methods for estimating flood flows. In such cases, rainfall-runoff models may be used for predicting catchment responses to designed rainfalls (Post and Jakeman 1999, Halwatura 
2013). The rainfall-runoff models can be classified under various conditions (Ozga-Zielińska 1976) but in practical approach it is fundamental to guarantee high quality of prediction and face difficulties in application (parameter identification, software running). Empirically based lumped hydrologic models have an extensive track record of use for various engineering applications (Paudel et al. 2011). Some studies indicate that a lumped parameter models can perform as good as distributed parameter models (Bahat et al. 2009), apart from that a calibration of lumped parameter models are simpler and less time consuming (Vansteenkiste et al. 2014).

A procedure called SEGMO (SedimentGraph Model), developed at Warsaw University of Life Sciences for analyzing rainfall-runoff events in small catchments and for predicting catchment responses to heavy rainfall (Banasik 1994, Banasik and Walling 1996, Banasik et al. 2000), was used in the investigation. It was proved in the previous investigations that SEGMO is useful tool for predicting flood hydrographs, as catchment response to extreme rainfalls (Banasik 2011).

This study tests the ability of the SEGMO model to simulate design storm runoff in Korean catchment, which is different from European climate. The aim of the study is to predicting responses to 100 -year rainfall events of small catchment of Jeungpyeong (South Korea), applying SEGMO and using two parallel approaches for model parameter estimation, i.e.: (1) based on catchment characteristics and USDA (1972) procedures (as for ungauged basin) and, (2) based on rainfall-runoff measurements, and fi- nally to compare both model outputs. It is assumed in the procedure, that rainfall of return period $T$, causes discharge of the same return period $T$, what is often accepted in engineering applications for events of low probability of appearance (USGS 2014).

\section{MATERIAL AND METHODS}

\section{Catchment characteristics}

The object of study is the Jeungpyeong river catchment, located in the central part of the South Korea (Fig. 1). It is rocated in the headwaters of the Guem river basin draining the central part of the Korean peninsula. Catchment area equals $133.6 \mathrm{~km}^{2}$, its elevation ranges from 51 to $631 \mathrm{~m}$ asl, and the mean catchment slope is ca. $15 \%$. Mean annual precipitation in the region is ca. $1,210 \mathrm{~mm}$ and mean annual temperature is $11.2^{\circ} \mathrm{C}$. Forests cover significant part of the catchment area $(46.7 \%)$ and are mainly located close to watershed boundary. Rice paddy (32.4\%) and other fields (15.5\%) are situated in the middle and the lower part of the watershed. Soils of low runoff potential as sand, loamy sand and sandy loam are dominating in the catchment, appearing on ca. $48 \%$ of catchment area mainly in the lowland, whereas silt loam, loam and sandy clay loam appear on ca. $39 \%$, and on remaining ca. $13 \%$ of catchment area appear soils of high runoff potential as clay loam, sandy clay, silty clay and clay. Described catchment characteristics were used to estimate the model parameters according to USDA-SCS (1972) procedures.

The Jeungpeong gaugeing station has been operated since 2004 and all hydro- 


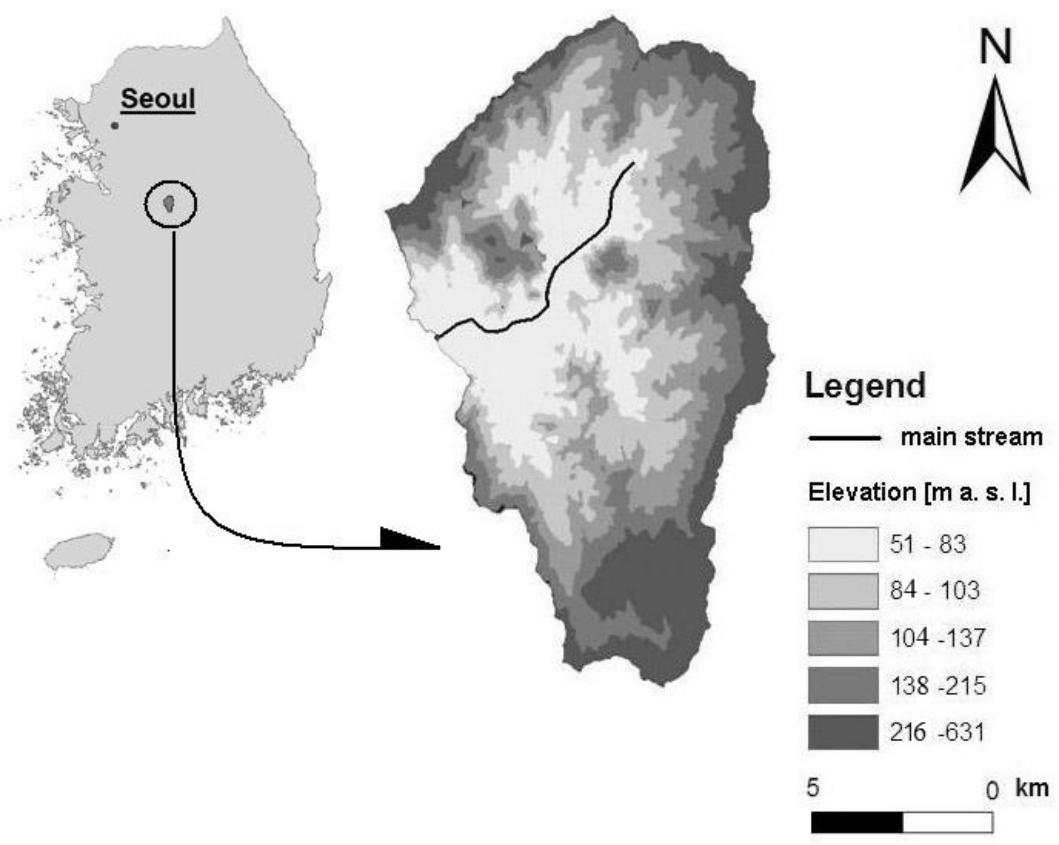

FIGURE 1. The Jeungpyeong river catchment (South Korea) - location and elevation map

logical data is managed by Ministry of Land, Infrastructure and Transport of Korea. The hydrological data, including rainfall and runoff observed time series, were obtained from Water Management Information System (WAMIS, http:// www.wamis.go.kr). The evapotranspiration data was derived by using the FAO Penman-Monteith method, suggested by the Food and Agriculture Organization of the United Nations (FAO 1998). The meteorological data, e.g. wind speed, temperature, relative humidity etc., was acquired from the Cheongju meteorological station. Seven recorded flood events in the period 2004-2008 were used for estimation of the model parameters in the other approach for flood predictions.

\section{Rainfall-runoff model}

Schematic representation of the rainfall-runoff model is shown on Figure 2. The model uses the Soil Conservation Service CN-method (USDA-SCS 1972, ASCE 2009) to estimate effective rainfall and the instantaneous unit hydrograph (IUH)

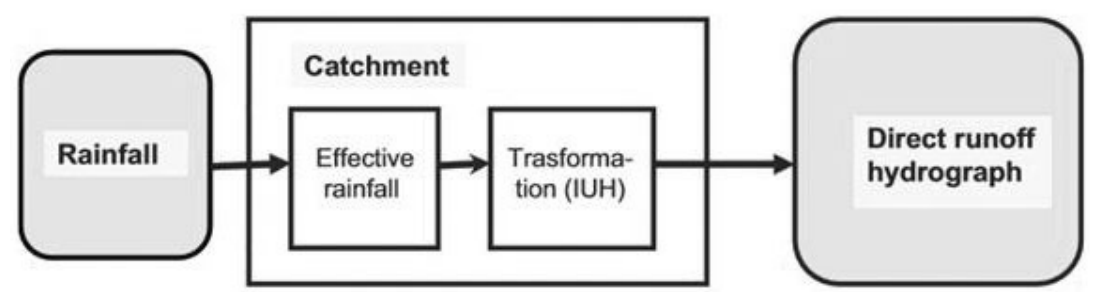

FIGURE 2. Schematic representation of rainfall-runoff model 
according to concept of Nash (1957), to transform the effective rainfall into a direct runoff hydrograph. Model input information are rainfall depth, its duration and time distribution. Base flow as having negligible value in comparison with direct flow, is not considered in the computation.

The Curve Number $(\mathrm{CN})$ method, developed by the Soil Conservation Service (USDA-SCS 1972) and commonly accepted by the Natural Resources Conservation Service (NRCS) of the U.S. Department of Agriculture (USDA) is probably the most widely used in hydrology and environmental engineering for determining amount of direct runoff from a rainfall event (ASCE 2009) in a particular area:

$H_{j}=\left\{\begin{array}{c}0 \\ \frac{\left(P_{j}-0.2 S\right)^{2}}{P_{j}+0.8 S}\end{array}\right.$

for $P_{j}-0.2 S \leq 0$

for $P_{j}-0.2 \mathrm{~S}>0$

$S=25.4\left(\frac{1000}{C N}-10\right)$

where:

$H_{j}$ - effective rainfall (i.e. runoff depth) at time $t_{j}$, i.e. from $t_{0}$ to $t_{j}\left(H_{j}=\sum_{i=1}^{j} \Delta H_{i}\right)$ (mm), $\Delta P_{i}, \Delta H_{i}$ - partial rainfall and partial effective rainfall $(\mathrm{mm})$,

$P_{j}$ - rainfall depth at time $t_{j}$, i.e. from $t_{0}$ to

$t_{j}\left(P_{j}=\sum_{i=1}^{j} \Delta P_{i}\right)(\mathrm{mm})$,

$S$ - maximum potential retention (mm),
$C N$ - Curve Number, i.e. catchment parameter in the range from 0 to 100 , which value depends on land use, soil type, hydrological conditions and soil moisture (-).

The effective rainfall estimated from equations 1 and 2 is transformed into direct runoff hydrograph with the use of unit hydrograph (UH). The unit hydrograph of a catchment is defined as a hydrograph resulting from effective rainfall of $1 \mathrm{~mm}$ distributed over the basin during the time $(\Delta t)$. An Instantaneous unit hydrograph (IUH) is a unit hydrograph resulting by effective rainfall having an infinitesimal duration $(\Delta t \rightarrow$ 0 ). The main advantage of IUH is that, it eliminates the problem of unit duration and restriction of uniform distribution of rainfall in time (Raghunath 2006). Out of many hydrographs, Nash IUH is considered as the simplest, the most practical and commonly used (Banasik et al. 2000, Mohan and Vijayalakshmi 2008, Sikorska and Banasik 2010). Nash proposed that the IUH can be obtained by routing instantaneous unit inflow through a cascade of $N$ linear reservoirs with retention parameter $k$ of each one. The outflow from the first reservoirs is an inflow into the second reservoir and so on, as shown on Figure 3. The mathematical expression of a presented concept is as follows:

$u(t)=\frac{1}{k \cdot \Gamma(N)}\left(\frac{t}{k}\right)^{N-1} \exp \left(-\frac{t}{k}\right)$

where:

$u(t)$ - ordinates of IUH $\left(\mathrm{h}^{-1}\right)$,

$N$ - number of linear reservoirs, parameter $(-)$,

$k$ - linear reservoir retention, parameter $\left(\mathrm{h}^{-1}\right)$, 

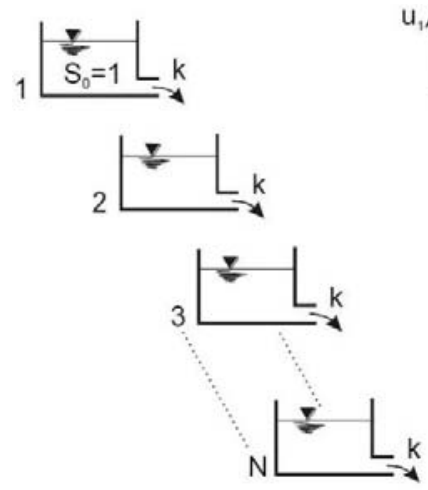
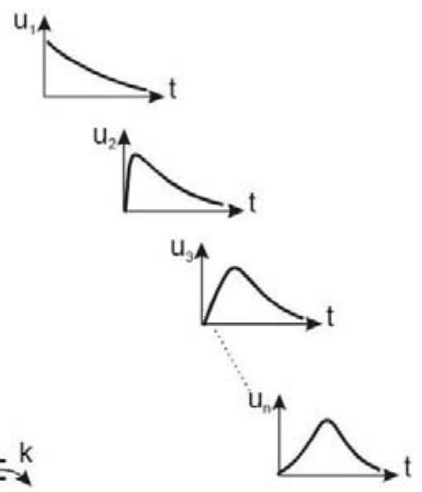

FIGURE 3. A concept of Nash model - cascade of linear reservoirs (Nash 1957)

$\Gamma(N)$ - gamma function (-),

$t$ - time from the beginning of coordinate system (h).

The characteristic values of IUH are time to peak and peak value, computed from the equations:

$t_{p}=(N-1) k$

and

$u_{p}=\frac{1}{k \cdot \Gamma(N)} \cdot \frac{(N-1)^{N-1}}{\exp (N-1)}$

where:

$u_{p}$ - peak value of IUH $\left(\mathrm{h}^{-1}\right)$,

$t_{p}$ - time to peak of IUH (h).

A direct runoff is calculated according to following equation:

$Q_{i}=\sum_{j=1}^{\min (i, n)} h_{k} \cdot \Delta H_{j}$

$k=i-j+1$

$i=1,2, \ldots, m+n-1$

where:

$Q_{i}$ - direct runoff ordinates $\left(\mathrm{m}^{3} \cdot \mathrm{s}^{-1}\right)$, $h_{k}$ - unit hydrograph ordinates

$\left(\mathrm{m}^{3} \cdot \mathrm{s}^{-1} \cdot \mathrm{mm}^{-1}\right)$

$m$ - number of unit hydrograph ordinates

$(-)$,

$n$ - number of effective rainfall intervals $(-)$,

$\Delta H_{j}$ - partial effective rainfall at $j$-time interval.

Ordinates of unit hydrographs are computed from formula:

$h_{k}=\frac{A}{3.6 \Delta t} \int_{t-\Delta t}^{t} u(t) \mathrm{d} t$

$t=\Delta t \cdot i \quad i=1,2, \ldots, m$

where:

$A$ - catchment area $\left(\mathrm{km}^{2}\right)$,

$\Delta t$ - computation time step (h).

To apply the above described procedure for predicting a catchment response to a designed rainfall event, one has to be in position to estimate the three model parameters: $C N$ of the SCS method for effective rainfall calculation, and $k$ and $N$ of the IUH according to Nash for transforming the effective rainfall into direct runoff hydrograph. 


\section{Model parameters estimation - case study}

Approach 1. The model parameters are estimated on the base on catchment characteristics and USDA-SCS (1972) procedures (as for ungauged catchment).

Theoretical (table) values of $C N$ are estimated on the basis of soil and land use maps, and for average soil moisture condition (also referred as CN-II) for a homogeneous parts of the catchment, using SCS guidelines (USDA-SCS 1972, 1986, 1992). The soil types are classified in the SCS procedure into four hydrologic soil groups, from A - with low runoff potential, to D - with high runoff potential. The structure of hydrologic soil groups in the Jeungpyeong catchment is showed on Figure 4. Table value for a catchment $\left(C N_{t a b}\right)$ is calculated as mean weighted values, according to following equation:

$C N_{W}=\frac{1}{A} \sum_{i=1}^{n} C N_{i} \Delta A_{i}$

where:

$C N_{W}$ - weighted average $C N$ for the catchment (-),
$A$ - catchment area $\left[\mathrm{km}^{2}\right]$,

$n$ - number of homogenous areas (-)

$C N_{i}-C N$ value for homogeneous part of the catchment, identified on the basis of cartographic materials and SCS tables (-), $\Delta A_{i}$ - area of homogeneous part $\left(\mathrm{km}^{2}\right)$.

Joo et al. (2014) gave table value of $C N$ for the catchment as $C N_{t a b}=70.5$.

The Nash IUH characteristics, i.e. time to peak and peak value, can be estimated on the basis of empirical equations (USDA-SCS 1972, Sikorska and Banasik 2010), with the use of some physical data of a catchment:

$$
\begin{aligned}
& t_{p}=\frac{L^{0.8}\left(\frac{1000}{C N}-9\right)^{0.7}}{2.92 s^{0.5}} \\
& u_{p}=\frac{0.75}{t_{p}}
\end{aligned}
$$

where:

$t_{p}$ - time to peak of IUH (h),

$L$ - length of the main stream, measured along the watercourse from catchment outlet to its boundary $(\mathrm{km})$, $s$ - mean catchment slope (\%).

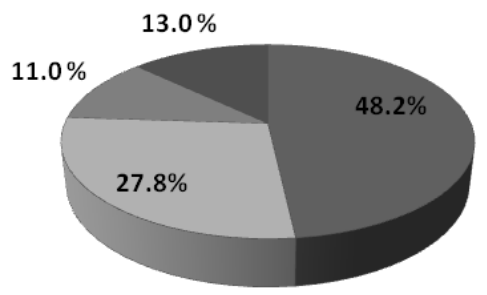

\footnotetext{
- Group A (sand, loamy sand, or sandy loam)

$\square$ Group B (silt loam or loam)

$\square$ Group C (sandy clay loam)

- Group D (clay loam, silty clay loam, sandy clay, silty, clay, or clay)
}

FIGURE 4. Hydrologic soil groups structure in the of Jeungpyeong catchment 
Having the two characteristics $t_{p}$ and $u_{p}$ one can get parameter $N$ (number of reservoirs), making use of the following equation, which is result of multiplication of right hand sides of equation 4 and 5:

$$
f(N)=\frac{1}{k \cdot \Gamma(N)} \cdot \frac{(N-1)^{N}}{\exp (N-1)}=t_{p} \cdot u_{p}
$$

and when $N$ is obtained, the other model parameters $k$ (retention time) can be estimated from $t_{p}$ and the equation 4 . The IUH characteristics were estimated as $t_{p}=2.02 \mathrm{~h}$ and $u_{p}=0.371 \mathrm{~h}^{-1}$, and the model parameters: $N=4.70$ and $k=0.55 \mathrm{~h}$.

Approach 2. The model parameters are estimated on the base on recorded rainfall-runoff events in the catchment (as for gauged basin). Characteristic of seven registered rainfall-runoff events are shown in Table 1. For five of seven events rainfall depth was ranging from 74 to $96 \mathrm{~mm}$, and for two it was significantly higher $-153.5 \mathrm{~mm}$ (11.07.09) and $238.6 \mathrm{~mm}$ (20.06.04). Rainfall from June 2004 caused the biggest catchment reaction, i.e. the peak discharge was close to $800 \mathrm{~m}^{3} \cdot \mathrm{s}^{-1}$ and on the other hand average peak discharge for all seven events was lower than $300 \mathrm{~m}^{3} \cdot \mathrm{s}^{-1}$.

Using measured rainfall-runoff data, the empirical value of $C N$ is estimated by solving equations 1 and 2 for retention $-S$, i.e. by the use of the relationship (Hawkins 1973):

$$
C N=\frac{25400}{S+254}
$$

where:

$S$ - catchment storage parameter $(\mathrm{mm})$.

TABLE 1. Characteristics and model parameters for recorded rainfall-runoff events

\begin{tabular}{|l|c|c|c|c|c|c|c|c|c|c|}
\hline & \multicolumn{4}{|c|}{ Event characteristics } & \multicolumn{2}{|c|}{$\begin{array}{c}\text { IUH } \\
\text { characteristics }\end{array}$} & \multicolumn{2}{|c|}{ Model parameters*) } \\
\cline { 2 - 12 } Date & $\begin{array}{c}\text { Rain } \\
P \\
(\mathrm{~mm})\end{array}$ & $\begin{array}{c}\text { Rain } \\
\text { dura- } \\
\text { tion } \\
D \\
(\mathrm{~h})\end{array}$ & $\begin{array}{c}\text { Runoff } \\
(\mathrm{mm})\end{array}$ & $\begin{array}{c}\text { Peak } \\
\text { disch. } \\
Q_{\text {peak }} \\
\left(\mathrm{m}^{3} \cdot \mathrm{s}^{-1}\right)\end{array}$ & $\begin{array}{c}\text { Lag } \\
\text { time } \\
\text { LAG } \\
(\mathrm{h})\end{array}$ & $\begin{array}{c}\text { Time } \\
\text { to peak } \\
t_{p} \\
(\mathrm{~h})\end{array}$ & $\begin{array}{c}\text { Peak } \\
\text { value } \\
u_{p} \\
\left(\mathrm{~h}^{-1}\right)\end{array}$ & $\begin{array}{c}C N \\
(-)\end{array}$ & $\begin{array}{c}N \\
(-)\end{array}$ & $\begin{array}{c}k \\
(\mathrm{~h})\end{array}$ \\
\hline 20.06 .04 & 238.6 & 21 & 158.8 & 798 & 2.69 & 0.00 & 0.371 & 74.5 & 1.00 & 2.69 \\
\hline 03.07 .05 & 74.1 & 18 & 42.8 & 210 & 4.87 & 0.92 & 0.157 & 87.2 & 1.23 & 3.95 \\
\hline 21.09 .05 & 96.0 & 24 & 74.4 & 171 & 7.98 & 1.29 & 0.098 & 92.3 & 1.19 & 6.69 \\
\hline 24.07 .06 & 80.6 & 9 & 45.6 & 191 & 4.69 & 0.55 & 0.172 & 85.8 & 1.13 & 4.15 \\
\hline 14.09 .07 & 79.4 & 15 & 30.1 & 120 & 6.83 & 2.09 & 0.107 & 77.4 & 1.44 & 4.73 \\
\hline 16.09 .07 & 82.5 & 20 & 62.3 & 233 & 6.40 & 1.17 & 0.120 & 92.6 & 1.22 & 5.23 \\
\hline 11.07 .09 & 153.5 & 20 & 46.2 & 348 & 1.65 & 0.00 & 0.606 & 58.4 & 1.00 & 1.65 \\
\hline Range & 74.1 & 9 & 30.08 & 120 & 1.65 & 0.00 & 0.098 & 58.4 & 1.00 & 1.65 \\
\hline Average & 238.6 & 24 & 158.8 & 798 & 7.98 & 2.09 & 0.606 & 92.6 & 1.44 & 6.69 \\
\cline { 2 - 12 }$y$ & 115.0 & 18.1 & 65.7 & 296 & 5.02 & 0.86 & 0.233 & 81.2 & 1.17 & 4.16 \\
\hline $\begin{array}{l}\text { Standard } \\
\text { deviation }\end{array}$ & 61.0 & 4.9 & 43.5 & 232 & 2.27 & 0.75 & 0.189 & 12.2 & 0.15 & 1.65 \\
\hline
\end{tabular}

${ }^{*}$ Notation: $C N$ is curve number, $N$ is number of reservoirs, $k$ is time of retention. 
Catchment storage can be computed from the formula:

$S=5\left(P+2 H-\sqrt{4 H^{2}+5 P H}\right)$

where:

$P$ - rainfall depth (mm),

$H$ - effective rainfall (mm).

In the analysis of single event rainfall-runoff data, the direct runoff was extracted from the total runoff hydrograph by applying straight line connecting arbitrary determined points of beginning of direct runoff and its ending. It was assumed, from definition of the effective rainfall, that direct runoff volume equals to effective rainfall volume over the basin. The $C N$ parameter of each recorded event of rainfall $\left(P_{j}\right)$ and runoff $\left(H_{j}\right)$ was calculated according to equations 12 and 13, and are shown in Table 1. Empirical $C N$ varies from 58.4 to 92.6 for the set of seven events, and its average value equals 81.2.

The distribution of the effective rainfall within its duration, what is needed for estimation of statistical moments, was calculated according to basic equations of SCS-CN (formulae 1 and 2), assuming time interval $\Delta t=1 \mathrm{~h}$.

It was indicated by Hawkins et al. (1985) and Banasik (1994), that the average value of $C N$ estimated from observed rainfall-runoff events gives an overestimate of effective rainfall depth when applied for prediction. Hawkins (1993) proposed a frequency matching concept for estimating the representative value of $C N$ for a catchment. This mean that firstly, rainfall-runoff data (as depths) are sorted separately; secondly, for recently created data pairs the $C N$ value are being calculated and thirdly, values of $C N$ versus the observed rainfall depths are related according the formula:

$C N(P)=C N_{\infty}+\left(100-C N_{\infty}\right) \exp \left(-\frac{P}{b}\right)$

where:

$C N_{\infty}-C N$ empirical for rainfall approaching infinity (-),

$P$ - rainfall depth (mm),

$b$ - parameter $(\mathrm{mm})$.

A tendency of declining $C N$ with increasing rainfall can be noticed (Fig. 5). For increasing rainfall depth the empirical $C N$ is approaching constant of $C N_{\infty}=68.6$. Presented method was efficiently applied in Poland in urban (Banasik et al. 2014) and rural catchments (Banasik and Woodward 2010, Banasik et al. 2014). Table Curve software "Automated curve fitting and equation discovery" (Systat Software Inc. 2002) has been used to find parameters of the formula 14 for the 7 pairs $\mathrm{P}: \mathrm{H}$ of the Jeungpyeong catchment.

If rainfall-runoff data of single events for a catchment are available, IUH parameters can be established with the use of the method of statistical moments:

$M_{1 Q}-M_{1 P}=N \cdot k=\mathrm{Lag}$

$M_{2 Q}-M_{2 P}=N \cdot k^{2}(N+1)+$

$+2 N \cdot k \cdot M_{1 P}$

where:

Lag - lag time, i.e. catchment response time (h),

$M_{1 P}$ and $M_{2 P}-$ first (h) and second $\left(\mathrm{h}^{2}\right)$ statistical moment of effective rainfall hyetograph, 


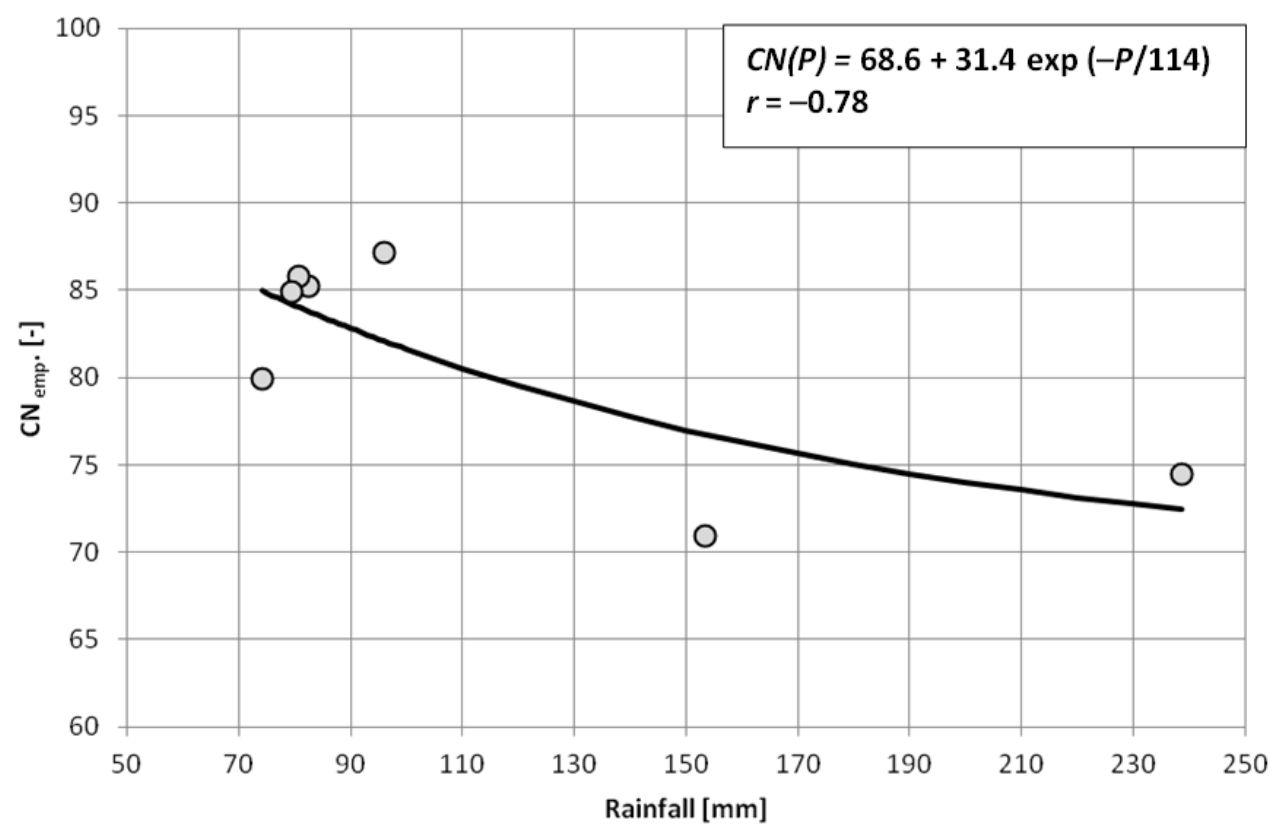

FIGURE 5. Values of $C N$ estimated from the $P: H$ pairs sorted separately versus rainfall depths for the watershed

$M_{1 Q}$ and $M_{2 Q}-$ first (h) and second $\left(\mathrm{h}^{2}\right)$ statistical moment of direct runoff hydrograph.

As model parameters, $N$ and $k$ for recorded events vary from event to event (Table 1), a way of Serban (after Banasik and Ignar 1986) is used to find the representative values for the catchment. Firstly, mean values of the IUH characteristics are computed from formulas:

$\overline{t_{p}}=\frac{\sum_{i=1}^{m} t_{p i}}{m}$

$\overline{u_{p}}=\frac{\sum_{i=1}^{m} u_{p i}}{m}$

where:

$\overline{t_{p}}$ - average time to peak of recorded IUHs (h), $\overline{u_{p}}$ - average peak of IUHs $\left(\mathrm{h}^{-1}\right)$, $t_{p i}$ - value of time to IUH peak for $i$-event (h),

$u_{p i}$ - value of IUH peak for $i$-event $\left(\mathrm{h}^{-1}\right)$, $m$ - number of events.

Secondly, using the mean values of $t_{p}$ and $u_{p}$, the model parameters $N$ and $k$ are computed as described in previous subsection, according equations 11 and 4. The estimated IUH parameters are: $N=1.37$ and $k=2.32 \mathrm{~h}$

Both sets of model parameters, i.e. the first one, estimated on the base of catchment characteristics and USDA-SCS procedures, and the second one, estimated on the base of single event rainfall-runoff records, are presented in Table 2. 
TABLE 2. Model parameters and its characteristics, according to the applied approaches

\begin{tabular}{|c|c|c|c|c|c|c|}
\hline Approach & Base of estimation & $\begin{array}{c}C N \\
(-)\end{array}$ & $\begin{array}{c}N \\
(-)\end{array}$ & $\begin{array}{c}k \\
(\mathrm{~h})\end{array}$ & $\begin{array}{c}t_{p} \\
(\mathrm{~h})\end{array}$ & $\begin{array}{c}u_{p} \\
\left(\mathrm{~h}^{-1}\right)\end{array}$ \\
\hline 1 & Catchment characteristics & 70.5 & 4.70 & 0.55 & 2.023 & 0.371 \\
\hline 2 & Rainfall-runoff records & 68.6 & 1.37 & 2.32 & 0.860 & 0.233 \\
\hline
\end{tabular}

\section{RESULTS AND DISCUSSION}

\section{$C N$ parameter and its impact on runoff depth}

One can notice that the average value of $C N$ estimated from recorded events as $C N_{\text {evg }}=81.2$ is higher than the table one, $C N_{t a b}=70.5$, significantly. This confirms, the above mentioned results of investigations, that averaged $C N$ estimated from rainfall-runoff records would overestimate runoff (effective rainfall) when applied for prediction (Hawkins 1993, Banasik 1994, Banasik et al. 2014). So for further study the empirical $C N$ estimated with use of "asymptotic approach", as $C N_{\text {emp }}=C N_{\infty}=68.6$ has been accepted. Nevertheless, it has been presented on Figure 6 how depth of runoff will change with design rain duration for the Jeungpyeong catchment, of return period of 100 years, for curve number assumed as average $C N_{\text {evg }}=81.2$, table $C N_{t a b}=$ $=70.5$ and empirical one $C N_{\text {emp }}=68.6$. Runoff calculated according to $C N_{\text {evg }}$ is significantly higher than the two other runoff values estimated for the remaining two curve numbers. The difference in runoff calculated for $C N_{t a b}=70.5$ and for $C N_{\text {emp }}=68.6$ is ranging from $3.2 \mathrm{~mm}$ for $D=1 \mathrm{~h}$ (at which rainfall depth is $P=107.0 \mathrm{~mm}$ and $\left.H_{\text {emp }}=35.1 \mathrm{~mm}\right)$ to $6.8 \mathrm{~mm}$ for $D=24 \mathrm{~h}$ (with $P=286.4 \mathrm{~mm}$ and $\left.H_{\text {emp }}=182.6 \mathrm{~mm}\right)$, i.e. from 9.1 to $3.7 \%$, respectively. This could be seen as good agreement of table curve number

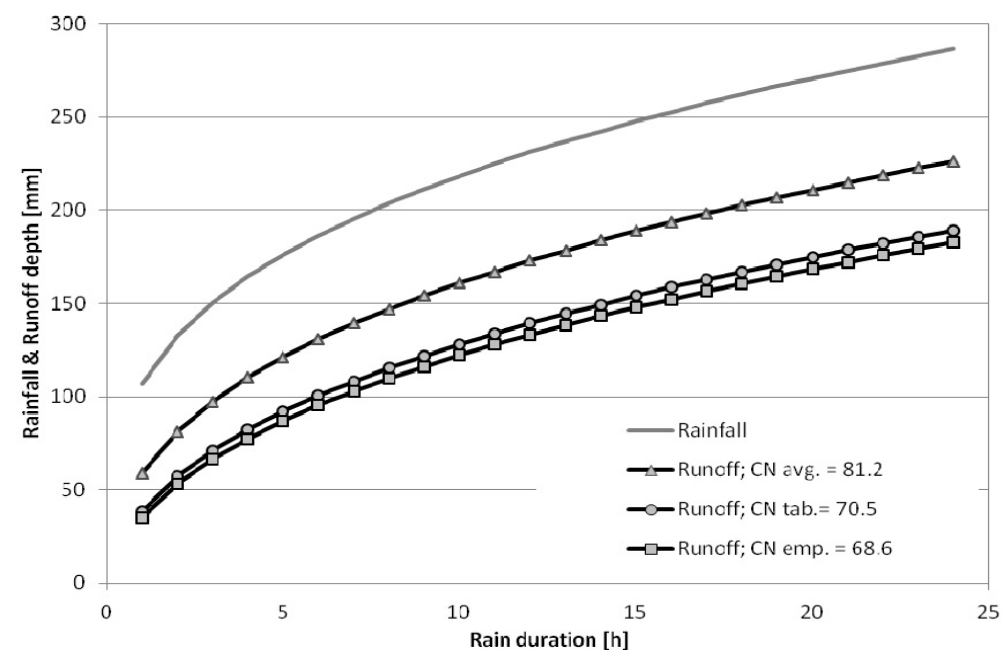

FIGURE 6. Rainfall depth and duration relationship of return period of 100 years with runoff depth for various values of $C N$ 
with empirical one, established with the use of Hawkins" "asymptotic approach".

\section{IUH parameters and their impact on transformation}

The Nash model parameters estimated according to approach 1, based on catchment characteristic, and according to approach 2, based on rainfall-runoff measurements, are given in Table 2 and the respective instantaneous unit hydrographs are shown on Figure 7. IUH estimated according to approach $1(N=$ $=4.70$ and $k=0.55 \mathrm{~h}$ ) has higher peak and its appearance is later than respective characteristics of IUH estimated acc. to approach $2(N=1.37$ and $k=2.32 \mathrm{~h})$. The values of peak ordinates are 0.371 and $0.233\left(\mathrm{~h}^{-1}\right)$ and time to peak 2.023 and 0.860 for the first and second approach, respectively. The relative large differences in characteristics of IUHs, i.e. of $60 \%$ in peak ordinates $[0.371-0.233) /$ $/ 0.233]$ and of $135 \%$ in time to peak [(2.023-0.860) / 0.860] will be reduced in the response of the catchment to heavy rainfall by the effect of convolution the IUH ordinates and effective rainfall.

\section{Direct runoff hydrographs}

Prediction of the flood hydrographs in the Jeungpyeong catchment has been done for two variants, i.e. for two sets of model parameters, which were estimated; (1) as for ungauged catchment and (2) on the base of rainfall-runoff records. Catchment responses have been simulated for rainfall events of return period of 100 years, of various duration, changing from 1 to $24 \mathrm{~h}$, with uniform distribution over the catchment and constant intensity in time. Results of computations are presented on Figures 8 and 9. According to the first variant of calculation, rainfall event of five hour duration is causing the direct runoff hydrograph with the largest peak discharge, which approaches $838 \mathrm{~m}^{3} \cdot \mathrm{s}^{-1}$. Maximum discharges obtained in the second variant are lower. For rainfall events of duration between five and nine hours the catchment responses are close to $600 \mathrm{~m}^{3} \cdot \mathrm{s}^{-1}$, with the

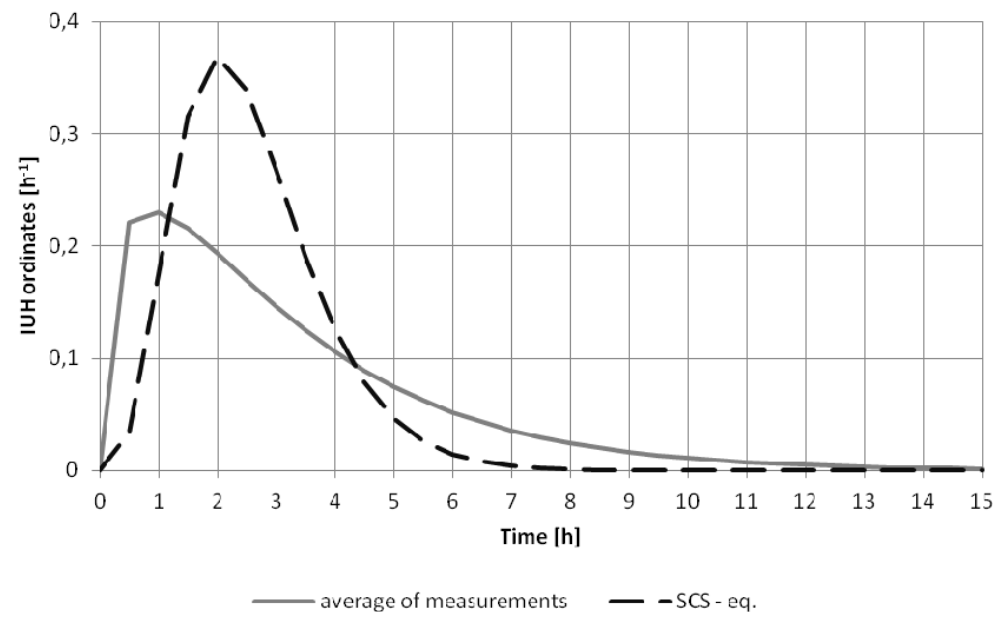

FIGURE 7. IUHs estimated on the basis of various methods 


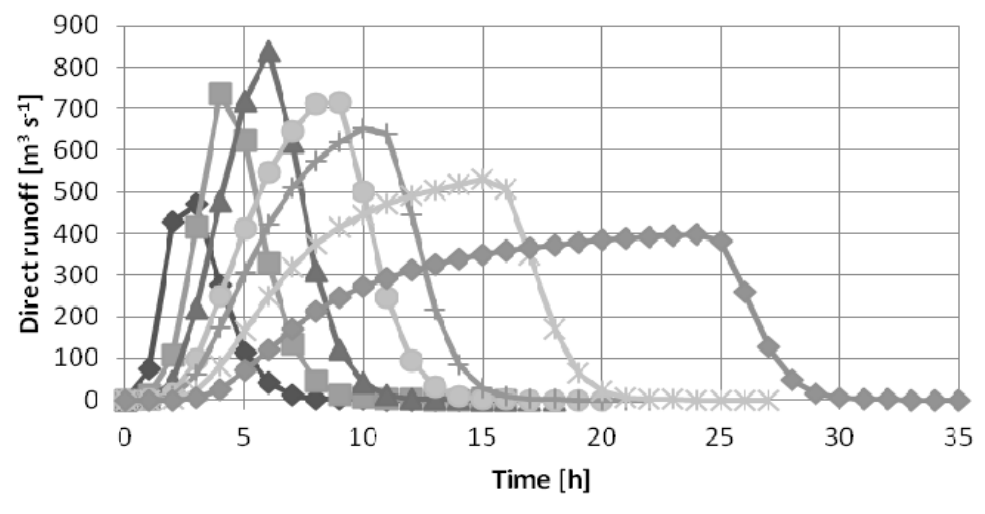

$$
\begin{aligned}
& \multimap \mathrm{D}=1 \multimap \mathrm{D}=3 \multimap \mathrm{D}=5 \multimap \mathrm{D}=8 \\
& \longrightarrow \mathrm{D}=10 \multimap \mathrm{D}=15 \multimap \mathrm{D}=24
\end{aligned}
$$

FIGURE 8. Predicted Jeungpyeong catchment responses to rainfall events of return period of 100 years and various durations $-\mathrm{D}$, with model parameters from literature methods

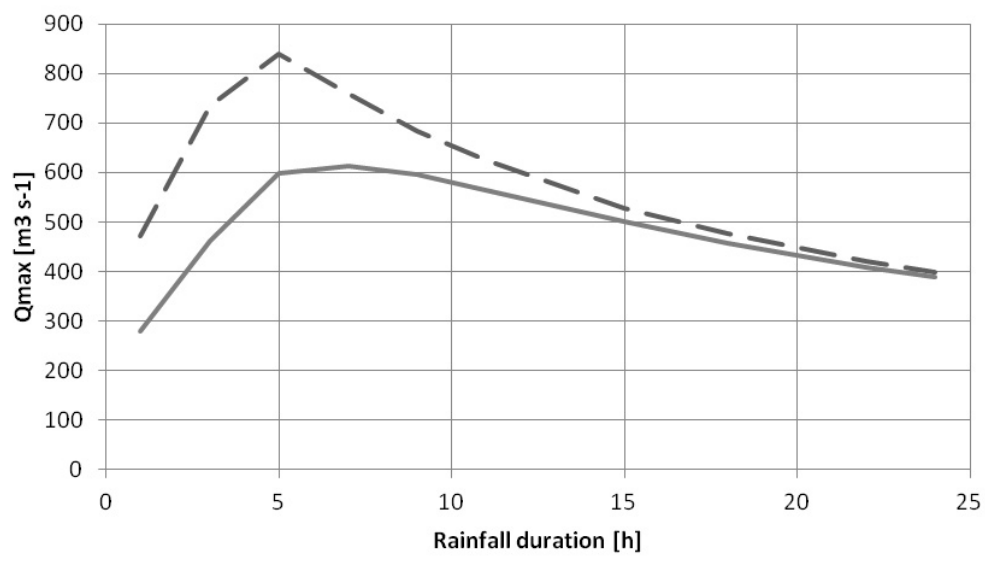

— - parameters acc. to literature methods

parameters acc. to measurments

FIGURE 9. Relationship of peak of direct hydrographs caused by rainfall of return period of 100 years versus rainfall duration for two sets of model parameters

largest value of $613 \mathrm{~m}^{3} \cdot \mathrm{s}^{-1}$ for rain duration of seven hours. So the critical rain duration were five and seven hours for the analyzed cases. The relative difference in the largest peak discharges estimated with the first and the other set of model parameters was $37 \%[(838-613) / 613]$.
Outputs obtained from variant number two seem to be more reliable. It should be keep in mind, that IUH shape impacts fully on results $\left(C N_{t a b} \approx C N_{e m p}\right)$. Parameters estimated on the basis of measurements take into account specific aspects of rainfall-runoff transformation, which 
can be in character of analyzed catchment. SCS equations give some general information about the process. They use only few topographic characteristic, what may not be sufficient for any case study.

Observed in June 2004 peak discharge $\left(798 \mathrm{~m}^{3} \cdot \mathrm{s}^{-1}\right)$ differ widely from highest simulated one with the second set of model parameters $\left(613 \mathrm{~m}^{3} \cdot \mathrm{s}^{-1}\right)$ and could be a results of higher precipitation $(239 \mathrm{~mm})$ than the design rainfall of 100 -year-return period and six-hour-duration $(196 \mathrm{~mm})$, as well as higher wetness in the catchment caused by preceded rainfall of depth $134 \mathrm{~mm}$. It leaded to high moisture content, elevated ground water level and water level in stream. We suppose that probability of exceedance for event from 20.06.2004 was less than $1 \%$.

\section{CONCLUSIONS}

1) The tested computer program SEG$\mathrm{MO}$, with incorporated lumped parametric rainfall-runoff procedure to simulate design storm runoff, proved its ability to predict responses of small Korean catchment to heavy rainfall events for case in which model parameters are estimated on the base of catchment characteristics and on the base of rainfall-runoff measurements.

2) This study confirmed that Curve Number of SCS, estimated in earlier study for the Jeungpyeong catchment on the base of land use and soil maps, and USDA-SCS tables, are very close to empirical value established with the use of Hawkins' "asymptotic approach" $\left(C N_{t a b} \approx C N_{e m p}\right)$.
3) The difference in largest peak discharges obtained from SEGMO with the two sets of model parameters, i.e. when estimated on the base of catchment characteristics and USDA-SCS procedures, which is suitable for ungauged basins, and the base on rainfall-runoff measurements were relatively small, approaching $37 \%$.

4) The largest peak discharged caused by rainfall of return period of 100 years estimated for Jeungpyeong catchment, with the use of model parameters based on measurement, amount to $613 \mathrm{~m}^{3} \cdot \mathrm{s}^{-1}$. According to the model investigation, the design rainfall events of duration from 5 to 9 hours cause responses with very similar peak hydrograph.

5) In the further study on assessing and reducing the uncertainties in rainfall-runoff modeling the following problems should be considered:

- when predicting flood flows in the Jeungpyeong catchment, the curve number should be assumed according the asymptotic equation as a value variable with the depth of rainfall,

- other reliable methods as regional formulas or flood frequency analysis should be also used to verify the results of computer simulation.

\section{Acknowledgment}

The investigation described in this paper has been conducted as part of the international research project KORANET (Join Call on Green Technologies) - EURRO-KPS founded by National Center for Research and Development (NCBiR), and by the National Research Founda- 
tion (NRF) of Korea. The support provided by the organizations is gratefully acknowledged.

\section{REFERENCES}

ANDERSEN T., SHEPHERD M. 2013: Floods in a Changing Climate. Geography Compass, 7/2, 95-115.

ASCE - American Society of Civil Engineers 2009: Curve Number Hydrology: State of the Practice. Eds. Hawkins R.H., Ward T.J., Woodward D.E. and Van Mullem J.A. American Society of Civil Engineers.

BAHAT Y., GRODEK T., LEKACH J., MORIN E. 2009: Rainfall-runoff modeling in a small hyper-arid catchment. Journal of Hydrology, 373(1-2), 204-217.

BANASIK K. 1994: Model sedymentogramu wezbrania opadowego $\mathrm{w}$ malej zlewni rolniczej [Sedimentgraph model of rainfall event in small agricultural watershed; in Polish with an English summary]. Theses \& Monographs of Warsaw Agricultural University - SGGW, 191.

BANASIK K. 2011: Catchment responses to heavy rainfall events in a changing environment. In: Prediction and reduction of diffuse pollution, solid emission and extreme flows from rural areas: case study of small agricultural catchments. Wyd. SGGW, Warszawa, 61-74.

BANASIK K., BYCZKOWSKI A., HEJDUK L., GŁADECKI J. 2012: Obliczanie przepływów maksymalnych rocznych o określonym prawdopodobieństwie przewyższenia $\mathrm{w}$ małej zlewni $\mathrm{z}$ zastosowaniem metod statystycznych oraz metod pośrednich [Estimation of probable flood flows in small catchments with the use of direct and indirect method]. Woda - Środowisko - Obszary Wiejskie, 3(39), 17-26. [Engl. Summ.].

BANASIK K., GÓRSKI D., IGNAR S. 2000: Modelowanie wezbrań opadowych i jakość odpływu z małych nieob- serwowanych zlewni rolniczych [Modeling of the runoff hydrographs and water quality from small ungauged agricultural catchments]. Wyd. SGGW, Warszawa.

BANASIK K., KRAJEWSKI A., SIKORSKA A., HEJDUK L. 2014: Curve Number estimation for a small urban catchment from recorded rainfall-runoff events. Archives of Environmental Protection, 40(3) (accepted for publication).

BANASIK K., WALLING D. 1996: Predicting sedimentgraphs for a small agricultural catchment. Nordic Hydrology, 27(4), 275-294.

BANASIK K., WOODWORD D. 2010: Empirical determination of runoff curve number for a small agricultural watershed in Poland. Joint 9th Federal Interagency Sedimentation Conference and 4th Federal Interagency Hydrologic Modelling Conference June.

BANASIK K., WOODWORD D., HAWKINS R. 2014: Curve Numbers for Two Agro-Forested Watersheds. World Environmental and Water Resources Congress 2014: Water without Borders, 2235-2246. ASCE, Portland, Oregon, June 1-5, 2014.

CASTELLARIN A., KOHNOVÀ S., GAÀL L., FLEIG A., SALINAS J., TOUMAZIS A., KJELDSEN T., MacDONALD N. 2012: Review of applied-statistical methods for flood-frequency analysis in Europe. Centre for Ecology \& Hydrology. United Kingdom.

EASH D. 1993: Estimating design - flood discharges for streams in Iowa using drainage basin and channel geometry characteristics. U.S. Geological Survey, Water - Resources Investigations Report 93-4062, Iowa City, Iowa.

HALWATURA D. 2013: Application of the HEC-HMS model for runoff simulation in a tropical catchment. Environmental Modelling \& Software, 46, 155-162.

HAWKINS R. 1973: Improved prediction of storm runoff in determination of curve numbers from data. Journal of Irrigation 
and Drainage Division. American Society of Civil Engineers, 99(4), 519-523.

HAWKINS R. 1993: Asymptotic determination of curve numbers from data. Journal of Irrigation and Drainage Division, American Society of Civil Engineers, 119(2), 334-345.

HAWKINS R., HJEMFELT J.R., ZEVENBERGEN A. 1985: Runoff probability storm depth and curve numbers. Journal of Irrigation and Drainage Division, 111(4), 330-340.

JOO J., KJELDSEN T., KIM J., LEE H. 2014: A Comparison of Two Event-based Flood Models (ReFH-rainfall Runoff Model and HEC-HMS) at Two Korean Catchments, Bukil and Jeungpyeong. KSCE Journal of Civil Engineering, 18(1), 330-343.

KARABOVÀ B., SIKORSKA A., BANASIK K., KOHNOVÀ S. 2012: Parameters determination of a conceptual rainfall - runoff model for a small catchment in Carpathians. Annals of Warsaw University of Life Sciences - SGGW. Land Reclamation, 44(2), 155-162.

MOHAN N., VIJAYALAKSHMI D. 2008: Estimation of Nash's IUH parameters using stochastic search algorithms. Hydrological Processes, 22( 17), 3507-3522.

NASH J. 1957: The form of the instantaneous unit hydrograph. IAHS Press, 59, 202-213.

OZGA-ZIELIŃSKA M. 1976: Metody opisu i analizy systemów hydrologicznych [Methods of description and analysis of the hydrological systems]. Prace Naukowe $P W, 49$.

PAP - Polish Press Agency 2010: Rzqd wyliczyl koszty powodzi [Government assessed the flood economic losses]. http://wiadomosci.onet.pl/kraj; Accessed 08.10.2010.

PAUDEL M., NELSON J., DOWNER C., HOTCHKISS R. 2011: Comparing the capability of distributed and lumped hydrologic models for analyzing the effects of land use change. Journal of Hydroinformatics 13.3, 461-473.
PEKÁROVÁ P., HALMOVÁ D., BAČOVÁMITKOVÁ V., MIKLÁNEK P., PEKÁR J., ŠKODA 2013: Historic flood marks and flood frequency analysis of the Danube River at Bratislava, Slovakia. J. Hydrol. Hydromech., 61, 4, 326-333.

POST D., JAKEMAN A. 1999: Predicting the daily streamflow of ungauged catchments in S.E. Australia by regionalizing the parameters of a lumped conceptual rainfall - runoff model. Ecological Modeling, (123), 91-104.

RAGHUNATH H. 2006: Instantaneous Unit Hydrograph. In: Hydrology: Principles, Analysis and Design. New Age International, Delhi.

SIKORSKA A., BANASIK K. 2010: Parameter identification of a conceptual rainfall-runoff model for a small urban catchment. Ann. Warsaw. Univ. of Life Sci. - SGGW. Land Reclamation, 42(2), 279-293.

SIKORSKA A., SCHEIDEGGER A., BANASIK K., RIECKERMANN J. 2013: Considering rating curve uncertainty in water level predictions. Hydrol. Earth Syst. Sci. 17, 4415-4427.

STRUPCZEWSKI W., KOCHANEK K., BOGDANOWICZ E. 2014: On return period of the largest historical flood. Journal of Geoscience and Environment Protection, 2, 144-152. doi: 10.4236/ gep.2014.23019.

VANSTEENKISTE T., TAVAKOLI M., VAN STEENBERGEN, N., De SMEDT F., BATELAAN O., PEREIRA F., WILLEMS P. 2014: Intercomparison of five lumped and distributed models for catchment runoff and extreme flow simulation. Journal of Hydrology, 511, 335-349.

USDA-SCS (Soil Conservation Service) 1972: National Engineering Handbook. Sec. 4. Hydrology. Washington D.C.

USDA-SCS (Soil Conservation Service) 1986: Urban hydrology for small watersheds. Tech. Report 55, US Dept. of Agric., Washington D.C.

USDA-SCS (Soil Conservation Service) 1992: Soil Survey of Barry County. Missouri. 
USGS-U.S. Geological Survey 2014: Floods: Recurrence intervals and 100-year floods. USGS science for a changing world. http://water.usgs.gov/edu/100yearflood. html (Accessed 02.05.2014).

Streszczenie: Przewidywane reakcje zlewni rzecznej na wysokie opady przy wykorzystaniu modelu SEGMO z dwoma zbiorami parametrów. Powodzie powodują straty społeczne, środowiskowe oraz ekonomiczne. Ryzyko związane $\mathrm{z}$ wystapieniem powodzi wzrasta wraz $\mathrm{z}$ obserwowanymi zmianami klimatu i dotyczy coraz szerszego kręgu mieszkańców globu. W związku z tym, politycy, planiści i projektanci potrzebuja informacji o skali zjawiska, które może wystapić. Informacja ta musi być jednocześnie jak najbardziej wiarygodna. W zlewniach obserwowanych hydrologicznie istnieje możliwość zastosowania metod statystycznych $\mathrm{w}$ celu oszacowania przepływów maksymalnych prawdopodobnych. Alternatywą w małych zlewniach, gdzie zwykle brak wieloletnich danych pomiarowych, a które są również bardziej podatne na zmiany wpływające na ich reakcje, jest stosowanie modeli opad - odpływ. W pracy przedstawiono zastosowanie modelu SEGMO do wyznaczenia reakcji rolniczo-leśnej zlewni Jeungpyeong, o powierzchni około $134 \mathrm{~km}^{2}$, położonej w centralnej części Korei Południowej na opad prawdopodobny o $\mathrm{p}=1 \%$ i różnym czasie trwania. Obliczenia wykonano w dwóch wariantach, określając parametry modelu: (1) na podstawie charakterystyki zlewni (jak dla zlewni nieobserwowanej) oraz (2) na podstawie pomiarów opad-odpływ. Przeprowadzone badania potwierdziły użyteczność modelu do symulacji reakcji zlewni na opady maksymalne, wysoką zgodność parametru $C N$ wyznaczania opadu efektywnego, ustalonego jako wartość tablicową $\mathrm{z}$ wartości $\mathrm{z}$ danych pomiarowych, oraz dobra zgodność wyników (maksymalnych przepływów) uzyskanych z zastosowania dwóch ww. sposobów ustalenia parametrów modelu. Wskazano na istotne elementy dalszych badań.

Stowa kluczowe: opad-odpływ, model SEGMO, SCS, CN, IUH Nasha, rzeka Jeungpyeong

MS. received August 2014

Authors' addresses:

Kazimierz Banasik

Wydział Budownictwa i Inżynierii Środowiska

SGGW

ul. Nowoursynowska 166

02-787 Warsaw

Poland

e-mail: kazimierz_banasik@sggw.pl

Hyosang Lee

Chungbuk National University

School of Civil Engineering

Ro-410 Heungduk Gu, 361-763 ChungJu, South Korea

e-mail: hyosanglee@chungbuk.ac.kr 